\title{
ANALISIS KOMPARATIF ANTARA BAHASA JAMEE (ACEH) DAN BAHASA MINANGKABAU (BUKITTINGGI)
}

\author{
Ramli \\ Universitas Syiah Kuala \\ rgadeng@yahoo.com
}

\author{
Novia Erwandi * \\ Dinas Pendidikan Aceh \\ erwandichaniago88@gmail.com
}

\begin{abstract}
Abstrak
Penelitian ini bertujuan untuk mengetahui perbedaan fonologi, leksikal, morfologi, dan struktur sintaksis antara bahasa Jamee dan bahasa Minangkabau Bukittinggi. Data dikumpulkan dengan teknik observasi dan wawancara. Sumber data dalam penelitian ini berasal dari lima penutur bahasa Jamee dan lima penutur bahasa Minangkabau Bukittinggi. Hasil penelitian menunjukkan adanya perbedaan fonologi, yaitu dalam sistem vokal bahasa Jamee terdapat $/ \mathbb{\varepsilon} /$ dan $/ \mathrm{o} /$, sedangkan dalam sistem vokal bahasa Minangkabau Bukittinggi terdapat/a/. Dalam sistem konsonan bahasa Jamee ditemukan $/ \mathrm{\gamma} /$ atau /R/, sedangkan dalam bahasa Minangkabau Bukittinggi ditemukan /r/. Juga ditemukan perbedaan pengucapan di antaranya vokal tunggal, vokal rangkap, dan konsonan. Perbedaan leksikal yang ditemukan dalam bahasa Jamee dan bahasa Minangkabau Bukittinggi hanya pada bentuk kata untuk makna yang sama. Perbedaan tersebut terdiri atas kata benda, kata sifat, kata kerja, dan kata keterangan. Untuk afiksasi, perbedaan terletak pada sisipan (infiks) $\{$-al- $\},\{$-ar- $\}$ dalam bahasa Jamee dan $\{$-am- $\},\{$-um- $\}$ dalam bahasa Minangkabau Bukittinggi, pada akhiran $\{$-en $\},\{-k e n\}$ dalam bahasa Jamee, $\{-$ kan $\}$ dalam bahasa Minangkabau Bukittinggi, dan konfiks \{me/-ken $\},\{$ me-/-en $\},\{$ ma-/-kan $\},\{$ ma-/-an $\}$ dalam bahasa Minangkabau Bukittinggi. Prefiks pada kedua bahasa memiliki kesamaan. Perbedaan juga terlihat dari kelas kata, baik verba, nomina, adjektiva, numeralia, dan adverbia. Dari segi jenis perulangan kata tidak ada perbedaan, hanya pada bentuk kata atau kata dasarnya, sedangkan struktur kalimat dari kedua bahasa memiliki kesamaan.
\end{abstract}

Kata Kunci: Analisis komparatif, bahasa Jamee, bahasa Minangkabau Bukittinggi

\begin{abstract}
The aim of this research is to find out the phonological, lexical, morphological, and syntactic differences between Jamee language and Minangkabau Bukittinggi language. Data were collected by means of observation and interview. The data sources in this research were from five speakers of Jamee language and five speakers of Minangkabau Bukittingi language. The results of the research show that there are phonological differences, in that there are $/ \varepsilon /$ and $/ \partial /$ in the vocal system of Jamee, while /a/ in the vocal system of Minangkabau Bukittinggi language. In the consonant system, Jamee has $/ \gamma /$ or $/ R /$, while $/ r /$ is found in Minangkabau Bukittinggi language. The pronunciation differences include single vowels, double vowels, and consonants. Lexical differences between the two languages are only found in lexical items having the same meaning, which include nouns, adjectives, verbs, and adverbs. For affixation, the difference lies in the infix \{-al-\}, \{-ar-\} in Jamee and \{-am-\}, \{-um-\} in Minangkabau Bukittinggi. The suffixes \{-en\}, \{-ken\} in Jamee, \{-kan\} in the Minangkabau Bukittinggi, and the confixes include \{me-/-ken\}, \{me-/-en\}, \{ma-/-kan\}, \{ma-/-an\} in Minangkabau Bukittinggi. The prefixes in the two languages are similar. Differences are also seen in word classifications such as verbs, nouns, adjectives, numeralia, and adverbs. As for the
\end{abstract}


types of word reduplications, the difference is only in the form of words or basic words. No differences are found in the syntactic structures of the two languages.

Keywords: Comparative analysis, Jamee language, Minangkabau Bukittinggi language

\section{PENDAHULUAN}

Bahasa Jamee merupakan bahasa yang digunakan di tiga kabupaten, yaitu Kabupaten Aceh Selatan atau di sebelah barat Provinsi Aceh, Kabupaten Aceh Barat atau wilayah barat pesisir Aceh, dan Kabupaten Singkil atau di sebelah selatan yang berbatasan langsung dengan Provinsi Sumatra Utara. Salah satu daerah penyebaran bahasa Jamee adalah Kabupaten Aceh Selatan. Bahasa Jamee memiliki perbedaan yang cukup signifikan dengan bahasa Minangkabau Bukittinggi, baik dari segi fonologi, leksikal, morfologi, maupun struktur kalimat. Bahasa ini berasal dari Minangkabau, Sumatra Barat, tetapi tidak seutuhnya sama karena adanya asimilasi daerah, yaitu dengan bahasa Aceh, yang membuat bahasa tersebut tidak lagi menjadi bahasa murni dari bahasa asal (Abdullah, Marlian, Rohana, \& Gade, 1990).

Sumatra Barat merupakan daerah asal bahasa Minangkabau. Daerah tersebut terbagi atas dua bagian, yaitu darek dan rantau. Darek adalah daerah tua Minangkabau yang terdiri atas tiga luhak, yaitu Luhak Tanahdatar, Luhak Agam, dan Luhak Limo Puluah Koto. Ketiga daerah tersebut terletak di sekitar Gunung Merapi, Singgalang, dan Sago. Luhak Tanahdatar di sekitar Gunung Merapi, Luhak Agam di sekitar Singgalang, dan Luhak Limo Puluah Koto di sekitar Gunung Sago. Daerah rantau meliputi pesisir pantai Sumatra Barat, di antaranya Padang, Pariaman, Pesisir Selatan, Kerinci, Natal, dan Indera Giri (Burhanuddin, 2009).

Bahasa Minangkabau (baso Minangkabau) adalah salah satu bahasa dari rumpun bahasa Melayu yang dituturkan oleh orang Minangkabau sebagai bahasa ibu, khususnya di Provinsi Sumatra Barat. Menurut Ayub (2008, p. 2), bahasa Minangkabau merupakan salah satu bahasa daerah yang hidup dan berasal dari rumpun Austronesia. Jadi, bahasa Minangkabau merupakan salah satu bahasa daerah yang dipakai penutur di Sumatra Barat sebagai komunikasi antarindividu atau antarkelompok. Bahasa ini tumbuh dan berkembang di wilayah Provinsi Sumatra Barat yang membujur dari barat laut hingga tenggara. Provinsi ini di sebelah utara berbatasan dengan Provinsi Sumatra Utara, di sebelah selatan berbatasan dengan Provinsi Jambi dan Bengkulu, di sebelah barat berbatasan dengan Samudra Indonesia, dan di sebelah timur berbatasan dengan Provinsi Riau (Moussay, 1998, p. 9).

Nababan (dalam Ayub, 2008, p. 3) menyatakan bahwa bahasa Minangkabau tidak saja dipakai di Sumatra Barat, tetapi juga di Malaysia, khususnya di Negeri Sembilan, kemudian di daerah Mukomuko (Provinsi Bengkulu), Natal, dan Barus (Provinsi Sumatra Utara), Tapaktuan (Provinsi Aceh), Bangkinang, Pekanbaru, dan Taluk di Provinsi Riau. Menyebarnya pemakaian bahasa Minangkabau ini karena penyebaran masyarakat pemakaiannya. Banyaknya masyarakat Minangkabau yang merantau atau migrasi ke daerah lain secara langsung atau tidak telah membantu penyebaran bahasa Minangkabau itu sendiri. Penyebaran ini menimbulkan adanya kontak bahasa antara bahasa masyarakat lokal dan bahasa Minangkabau sebagai pendatang.

Menurut Abdullah, Marlian, Rohana, \& Gade (1990, p. 19), salah satu bahasa yang mengalami kontak dengan bahasa Minangkabau adalah bahasa Jamee. Bahasa daerah ini telah tumbuh dan berkembang di Pantai Barat Selatan, Provinsi Aceh. Bahasa ini merupakan bahasa percampuran antara bahasa Minangkabau dan bahasa Aceh. Bahasa Jamee yang dipakai oleh penutur Aneuk Jamee memiliki persamaan dan perbedaan dengan bahasa Minangkabau dan 
bahasa Aceh. Persamaan dan perbedaan ini disebabkan asimilasi bahasa lokal (Aceh) yang mengintervensi bahasa Minangkabau.

Sumber sejarah yang menceritakan kedatangan suku Minangkabau ke wilayah Aceh amatlah terbatas dan sebagian besar lebih bersifat sumber lisan. Mengenai kedatangan orang Minangkabau itu, M. Zainuddin (dalam Sufi, 1961, p. 211) menyatakan bahwa sewaktu terjadinya Perang Paderi di Minangkabau, Sumatra Barat tahun 1805-1836, banyak orang Minangkabau menghindar dari malapetaka perang tersebut dengan cara berimigrasi menyusuri Pantai Barat Selatan Aceh (Pasir Karam). Pada abad ke-17 tersebut, pesisir barat sampai ke Indrapura/Bengkulu masuk ke dalam wilayah pengaruh Aceh.

Orang-orang Minangkabau yang datang untuk berdomisili di Pesisir Barat Selatan Aceh itu dianggap sebagai tamu yang berasimilasi dengan penduduk setempat (tamu dalam bahasa Aceh disebut jamee). Proses asimilasi ini berlangsung secara baik karena persamaan akidah, yaitu agama Islam. Dengan asimilasi tersebut, mereka tidak lagi merasa sebagai orang Minangkabau dan orang Aceh. Mereka meyatakan sebagai Aneuk Jamee (anak tamu).

Komunitas Aneuk Jamee mempunyai bahasa sendiri, yaitu bahasa Aneuk Jamee atau bahasa Jamee, yang hampir sama dengan bahasa Minangkabau. Mereka tidak terkonsentrasi di tempat tertentu, tetapi menyebar. Misalnya, suatu kecamatan tidak hanya ditempati oleh suku Aneuk Jamee, tetapi bercampur dengan suku Aceh. Paling hanya desa yang membedakan komunitasnya. Namun, di desa-desa di Aceh Selatan dapat juga kita jumpai orang berbicara dalam dua bahasa, yaitu bahasa Aceh dan Jamee. Ini terjadi karena adanya hubungan famili dengan orang yang berbahasa Aceh di desa lain. Penggunaan bahasa Jamee di Provinsi Aceh tersebar di tiga kabupaten, yaitu Kabupaten Aceh Selatan atau di sebelah barat Provinsi Aceh, di Kabupaten Aceh Barat atau wilayah barat pesisir, dan di Kabupaten Singkil atau di sebelah Selatan yang berbatasan langsung dengan Provinsi Sumatra Utara.

Sampel persamaan dan perbedaan nomina bahasa Minangkabau dan bahasa Jamee dapat dilihat pada beberapa contoh berikut ini.

Tabel 1. Persamaan Bahasa Jamee dengan Bahasa Minangkabau Bukittinggi

\begin{tabular}{cccc}
\hline No. & Bahasa Jamee & Bahasa Minangkabau Bukittinggi & Bahasa Indonesia \\
\hline 1 & asok & asok & asap \\
\hline 2 & galang & galang & gelang \\
\hline 3 & gusi & gusi & gusi \\
\hline 4 & tapai & tapai & tape \\
\hline 5 & gatah & gatah & getah \\
\hline
\end{tabular}

Tabel 2. Perbedaan Bahasa Jamee dengan Bahasa Minangkabau Bukittinggi

\begin{tabular}{cccc}
\hline No. & Bahasa Jamee & Bahasa Minangkabau Bukittinggi & Bahasa Indonesia \\
\hline 1 & ujen & hujan & hujan \\
\hline 2 & moto & oto & mobil \\
\hline 3 & ampang & karuang & karung \\
\hline 4 & sakin & pisau & pisau \\
\hline 5 & buluah gadang & batuang & bambu besar \\
\hline
\end{tabular}

Penelitian sejenis ini pernah dilakukan sebelumnya oleh Hasanah (2015) dengan judul Analisis Komparatif Antara Bahasa Jawa Dialek Jember dan Bahasa Jawa Standar. Dalam hasil penelitiannya, ditemukan adanya perbedaan leksikal, afiksasi, dan struktur kalimat dari 
kedua dialek bahasa tersebut, padahal kedua dialek tersebut berasal dari bahasa serumpun. Temuan ini mendorong penulis untuk melakukan penelitian dengan objek yang berbeda karena berdasarkan observasi dan literatur, ternyata bahasa Jamee dan bahasa Minangkabau Bukittinggi memiliki keterkaitan yang sangat erat.

\section{METODOLOGI PENELITIAN}

Pendekatan yang digunakan dalam penelitian ini adalah pendekatan kualitatif. Pendekatan ini sesuai untuk digunakan berdasarkan beberapa asas metodologis pendekatan kualitatif terhadap analisis komparatif antara bahasa Jamee dan bahasa Minangkabau Bukittinggi. Beberapa alasan yang mendasarinya adalah (1) sumber data dan data analisis komparatif antara bahasa Jamee dan bahasa Minangkabau Bukittinggi bersifat naturalistik; (2) data penelitian bersifat deskriptif dan data yang terkumpul berbentuk kata-kata; (3) penelitian ini lebih mengarah pada proses daripada hasil; (4) analisis data bersifat induktif; (5) peneliti merupakan instrumen kunci; dan (6) penelitian ini lebih menekankan pada unsur makna (Sugiyono, 2005, p. 10).

Sumber data dalam penelitian ini adalah penutur dari tiap-tiap bahasa, baik bahasa Jamee maupun bahasa Minangkabau Bukittinggi. Dalam penelitian ini ditentukan sebanyak sepuluh orang dengan rincian lima orang dari penutur bahasa Jamee dan lima orang dari penutur bahasa Minangkabau Bukittinggi. Lima orang dari penutur bahasa Jamee diambil dari penutur yang merantau di Banda Aceh dan lima penutur bahasa Minangkabau Bukittinggi diambil dari penutur yang merantau di Takengon (Aceh Tengah) yang merupakan famili peneliti sendiri. Dalam penelitian dialek ini, informan dipilih berdasarkan kriteria sebagai berikut (Mahsun, 2005, p. 134):

(1) Penutur asli bahasa Jamee dan bahasa Minangkabau Bukittinggi

(2) Berjenis kelamin laki-laki atau perempuan

(3) Berusia antara 25--65 tahun (tidak pikun)

(4) Lahir dari tempat asal

(5) Berpendidikan minimal tamat pendidikan dasar (SD-SLTP)

(6) Sehat jasmani dan rohani

Teknik pengumpulan data adalah dengan observasi dan wawancara. Observasi diarahkan pada pemakaian bahasa secara lisan mengenai perbedaan bahasa yang digunakan oleh penutur. Pengamatan dilakukan di lapangan. Dalam hal ini, peneliti langsung terjun mengamati sekaligus bertutur dengan penutur bahasa Jamee sebelum penelitian dimulai. Selain itu, peneliti juga mengamati tuturan dari beberapa informan, baik dari bahasa Jamee maupun bahasa Minangkabau Bukittinggi. Peneliti mengamati perbedaan data ini sebelum penelitian dilakukan di Banda Aceh, yaitu pada saat perkuliahan ketika berkomunikasi langsung dengan penutur bahasa Jamee yang berasal dari Aceh Selatan dan bahasa Minangkabau Bukittinggi di lingkup keluarga dan lingkungan di daerah Takengon, khususnya wilayah Blangmersa.

Wawancara dalam penelitian ini menggunakan metode cakap teknik pancing dan catat. Metode cakap teknik pancing digunakan untuk menggali data dari bahasawan yang tidak lain adalah kompetensi penutur asli kedua bahasa, yaitu bahasa Jamee perantau di Banda Aceh dan bahasa Minangkabau Bukittinggi perantau di Takengon. Setelah berhasil menggali data dari bahasawan, digunakan teknik catat agar data yang diperoleh lebih jelas dan tertata dengan baik. Metode cakap teknik pancing yang digunakan di lapangan adalah wawancara tak terstruktur. 
Wawancara tak terstruktur yang dimaksudkan di sini adalah wawancara bebas dan peneliti tidak menggunakan pedoman wawancara yang disusun secara sistematis dan lengkap untuk pengumpulan datanya. Teknik pengumpulan catat ini menggunakan data tulis, yaitu daftar klasifikasi atau kelas kata, baik nomina, verba, adjektiva, numerelia, maupun adverbia, serta wawancara tak terstruktur dengan penutur asli mengenai masalah keterkaitan kelas kata tersebut.

\section{HASIL DAN PEMBAHASAN}

\section{Perbedaan Fonologi Bahasa Jamee dan Bahasa Minangkabau Bukittinggi}

Fonologi bahasa Jamee berbeda dari bahasa Minangkabau Bukittinggi. Perbedaan ini disebabkan oleh berbagai faktor, di antaranya letak geografis, lingkungan, serta percampuran budaya dan bahasa penutur bahasa setempat. Perbedaan segi fonologi terletak pada sistem vokal dan sistem konsonan. Berikut ini pembahasan untuk sistem vokal (3.1.1), sistem konsonan (3.1.2), dan perbedaan pengucapan antara bahasa Jamee dan bahasa Minangkabau Bukittinggi (3.1.3).

\subsection{Sistem Vokal}

Vokal / $\varepsilon /$ dan $/ \partial /$ merupakan vokal yang terdapat dalam bahasa Jamee, sedangkan dalam bahasa Minangkabau Bukittinggi vokal tersebut tidak ditemukan. Selain itu, terdapat juga perbedaan pada vokal rangkap, yaitu vokal rangkap /ue/, /ie/, dan /ui/. Vokal rangkap /ue/, /ie/, dan /ui/ merupakan vokal rangkap bahasa Jamee dan vokal rangkap /ua/, /ie/, dan /ia/ merupakan vokal rangkap dari bahasa Minangkabau Bukittinggi. Perbedaan fonologi dari segi vokal dapat dilihat pada tabel di bawah ini.

Tabel 3. Sistem Vokal Bahasa Jamee

\begin{tabular}{ccccc}
\hline \multicolumn{2}{c}{ Posisi lidah } & \multicolumn{3}{c}{ Fonem } \\
\hline \multicolumn{2}{c}{ Tinggi } & Depan & Tengah & Belakang \\
\hline \multirow{2}{*}{ Sedang } & Atas & $\mathrm{i}$ & $\mathrm{u}$ \\
\cline { 2 - 5 } & Bawah & $\mathrm{e}$ & $\mathrm{o}$ & $\mathrm{0}$ \\
\hline Rendah & & & $\mathrm{a}$ & \\
\hline
\end{tabular}

Berdasarkan tabel di atas, sistem vokal bahasa Jamee mencakup vokal sebagai berikut.
a. 2 vokal tinggi
$: / \mathrm{i} / \mathrm{lu} /$
b. 2 vokal sedang atas : $/ \mathrm{e} / \mathrm{lo} /$
c. 2 vokal sedang bawah : :/ $/ / / \mathrm{o} /$
d. 1 vokal rendah
$: / \mathrm{a} /$

Tabel 4. Sistem Vokal Bahasa Minangkabau Bukittinggi

\begin{tabular}{cccc}
\hline Posisi lidah & \multicolumn{3}{c}{ Fonem } \\
\hline Tinggi & Depan & Tengah & Belakang \\
\hline Sedang & i & & u \\
\hline Rendah & e & & o \\
\hline
\end{tabular}


Berdasarkan tabel di atas, sistem vokal bahasa Minangkabau Bukittinggi mencakup vokal sebagai berikut.

a. 2 vokal tinggi : /i/ /u/

b. 2 vokal tengah :/e/ /o/

c. 1 vokal rendah : /a/

\subsection{Sistem Konsonan}

Pada sistem konsonan, perbedaan terletak pada konsonan $/ y /$ (R) dan $/ r /$ Konsonan $/ \mathrm{y} /$ merupakan konsonan bahasa Jamee, sedangkan konsonan $|r|$ merupakan konsonan bahasa Minangkabau Bukittinggi. Perhatikan Tabel 5 di bawah ini.

Tabel 5. Sistem Konsonan Bahasa Jamee

\begin{tabular}{cccccccc}
\hline & & Bilabial & Dental & Alveolar & Palatal & Velar & Glotal \\
\hline \multirow{2}{*}{ Oklusif } & Tak bersuara & $\mathrm{p}$ & $\mathrm{t}$ & & $\mathrm{c}$ & $\mathrm{k}$ & \\
\cline { 2 - 8 } & Bersuara & $\mathrm{b}$ & $\mathrm{d}$ & & $\mathrm{j}$ & $\mathrm{g}$ & \\
\hline \multirow{2}{*}{ Frikatif } & Tak bersuara & & & $\mathrm{s}$ & & & \\
\cline { 2 - 8 } & Bersuara & & & & & $\mathrm{\gamma}$ & $\mathrm{h}$ \\
\hline Sengau & & $\mathrm{m}$ & $\mathrm{n}$ & & $\mathrm{n}$ & $\mathrm{\eta}$ & \\
\hline Sampingan & & & & $\mathrm{l}$ & & & \\
\hline Semivokal & & $\mathrm{w}$ & & & $\mathrm{y}$ & & \\
\hline
\end{tabular}

Berdasarkan tabel di atas, sistem konsonan bahasa Jamee mencakup konsonan sebagai berikut.
a. 4 oklusif tak bersuara
$/ \mathrm{p} \mathrm{t} \mathrm{ck} /$
b. 4 oklusif bersuara
$/ \mathrm{b} \mathrm{d} \mathrm{j} \mathrm{g/}$
c. 4 sengau
$/ \mathrm{mn} \mathrm{n} \mathrm{h}$
d. 1 frikatif tak bersuara /s/
e. 1 frikatif bersuara $/ \mathrm{h} /$
f. 1 frikatif bersuara $/ \mathrm{\gamma} /(\mathrm{R})$
g. 1 sampingan
$/ \mathrm{l} /$
h. 2 semivokal
/w y/

Tabel 6. Sistem Konsonan Bahasa Minangkabau Bukittinggi

\begin{tabular}{|c|c|c|c|c|c|c|c|}
\hline & & Bilabial & Dental & Alveolar & Palatal & Velar & Glotal \\
\hline \multirow{2}{*}{ Oklusif } & Tak bersuara & $\mathrm{p}$ & $\mathrm{t}$ & & $\mathrm{c}$ & $\mathrm{k}$ & \\
\hline & Bersuara & $\mathrm{b}$ & $\mathrm{d}$ & & $\mathrm{j}$ & $\mathrm{g}$ & \\
\hline \multirow{2}{*}{ Frikatif } & Tak bersuara & & & $\mathrm{s}$ & & & \\
\hline & Bersuara & & & & & & $\mathrm{h}$ \\
\hline Sengau & & $\mathrm{m}$ & $\mathrm{n}$ & & $\mathrm{n}$ & $\eta$ & \\
\hline Vibran & & & & $\mathrm{r}$ & & & \\
\hline Sampingan & & & & 1 & & & \\
\hline Semivokal & & $\mathrm{W}$ & & & $\mathrm{y}$ & & \\
\hline
\end{tabular}

Berdasarkan tabel di atas, sistem konsonan bahasa Minangkabau Bukittinggi mencakup konsonan sebagai berikut.
a. 4 oklusif tak bersuara
$/ \mathrm{p} \mathrm{tck} /$ 


$\begin{array}{ll}\text { b. } 4 \text { oklusif bersuara } & \text { /b d j g/ } \\ \text { c. } 4 \text { sengau } & \text { /m n n } / \\ \text { d. } 1 \text { frikatif tak bersuara } & / \mathrm{s} / \\ \text { e. } 1 \text { frikatif bersuara } & / \mathrm{h} / \\ \text { f. } 1 \text { vibran } & / \mathrm{r} / \\ \text { g. } 1 \text { sampingan } & / \mathrm{l} / \\ \text { h. } 2 \text { semivokal } & / \mathrm{w} \mathrm{y} /\end{array}$

\subsection{Perbedaan Pengucapan}

Pengucapan bahasa Jamee juga berbeda dengan bahasa Minangkabau Bukittinggi. Perbedaan itu terletak pada vokal, baik vokal tunggal maupun vokal rangkap. Perbedaan-perbedaan tersebut dapat dilihat antara lain pada kata-kata seperti /maken//makan/, /pansen//pansan/, /bsRa//bara/, Imalsm/ /malam/. Kata maken, pansen, bora, malsm merupakan contoh dari bahasa Jamee, sedangkan kata makan, pansan, bara, malam merupakan contoh dari bahasa Minangkabau Bukittinggi. Kemudian, vokal rangkap dari kedua bahasa tersebut juga memiliki perbedaan yang terletak pada vokal rangkap akhir, seperti /giuel /giual, Imantuel Imantual, Ibacukuil Ibacukual. Kata giue, mantue, bacukui merupakan contoh dari bahasa Jamee, sedangkan kata giua, mantua, bacukua merupakan kata yang berasal dari bahasa Minangkabau Bukittinggi.

Perbedaan juga ada pada konsonan kedua bahasa. Perbedaan tersebut dapat dilihat seperti kata /saRewal, /sarawal, /kaRambiel, Ikarambial. Dari kedua contoh tersebut, terdapat perbedaan pengucapan konsonan /r/ tiap-tiap bahasa. Konsonan /r/ dilambangkan /R/ pada bahasa Jamee, sedangkan konsonan /r/ dilambangkan /r/ bahasa Minangkabau Bukittinggi. Huruf konsonan $\langle r\rangle$ pada bahasa Jamee vibrasinya tidak terlalu jelas, tetapi masih terasa getaran di bawah dagu, sedangkan $<r>$ pada bahasa Minangkabau Bukittinggi vibrasinya sangat jelas.

Contoh-contoh di bawah ini menunjukkan perbedaan pengucapan pada vokal maupun konsonan dari kedua bahasa.

Vokal tunggal $[\varepsilon]$ dan [a]

\begin{tabular}{|c|c|c|}
\hline$[\varepsilon](\mathbf{B J})$ & [a] $(\mathbf{B M B})$ & Arti \\
\hline maken & makan & makan \\
\hline pansen & pansan & pingsan \\
\hline bulcn & bulan & bulan \\
\hline tącn & tangan & tangan \\
\hline saRewa & sarawa & celana \\
\hline santen & santan & santan \\
\hline
\end{tabular}

Berdasarkan data yang dipaparkan tersebut, dapat disimpulkan bahwa $[\varepsilon]$ dalam bahasa Jamee adalah [a] dalam bahasa Minangkabau Bukittinggi apabila bunyi $[\varepsilon]$ terdapat pada suku kata akhir dan berakhir dengan bunyi [n].

Vokal tunggal [o] dan [a]

a. Suku kata awal

$\begin{array}{lll}\text { [0] }(\mathbf{B J}) & \text { [a] }(\mathbf{B M B}) & \text { Arti } \\ \text { boRa } & \text { bara } & \text { berapa } \\ \text { koma } & \text { kama } & \text { ke mana } \\ \text { monga } & \text { manga } & \text { sedang ngapain }\end{array}$


b. Suku kata akhir

$\begin{array}{lll}\text { [o] } \mathbf{( B J}) & {[\mathbf{a}](\mathbf{B M B})} & \text { Arti } \\ \text { malom } & \text { malam } & \text { malam } \\ \text { aysm } & \text { ayam } & \text { ayam } \\ \text { kalom } & \text { kalam } & \text { kalam } \\ \text { itsm } & \text { itam } & \text { hitam } \\ \text { garom } & \text { garam } & \text { garam } \\ \text { karom } & \text { karam } & \text { tenggelam } \\ \text { baysm } & \text { bayam } & \text { bayam }\end{array}$

Berdasarkan data yang dipaparkan tersebut, dapat disimpulkan bahwa [0] dalam bahasa Jamee adalah [a] dalam bahasa Minangkabau Bukittinggi apabila bunyi [0] terdapat pada suku kata akhir dan bertemu dengan bunyi [m].

Vokal Rangkap (Diftong)

$\begin{array}{lll}\text { [ue] }(\text { BJ) } & \text { [ua] BMB } & \text { Arti } \\ \text { ukue } & \text { ukua } & \text { ukur } \\ \text { giue } & \text { giua } & \text { giur } \\ \text { mundue } & \text { mundua } & \text { mundur }\end{array}$

Berdasarkan data yang dipaparkan di atas, dapat disimpulkan bahwa vokal rangkap akhir tiap-tiap bahasa berbeda. Vokal rangkap akhir [ue] merupakan pengucapan bahasa Jamee, sedangkan vokal rangkap akhir $[\mathrm{ua}]$ merupakan pengucapan bahasa Minangkabau Bukittinggi.

$\begin{array}{lll}\text { [ie] }(\mathbf{B J}) & {[\mathbf{i a}] \mathbf{B M B}} & \text { Arti } \\ \text { jungkie } & \text { jungkia } & \text { jungkir } \\ \text { singkie } & \text { singkia } & \text { singkir } \\ \text { ampie } & \text { ampia } & \text { hampir }\end{array}$

Berdasarkan data di atas, dapat disimpulkan bahwa vokal rangkap akhir tiap-tiap bahasa berbeda. Vokal rangkap akhir [ie] merupakan pengucapan bahasa Jamee, sedangkan vokal rangkap akhir $[i a]$ merupakan pengucapan bahasa Minangkabau Bukittinggi.

$\begin{array}{lll}\text { [ui] }(\mathbf{B J}) & \text { [ua] } \mathbf{B M B} & \text { Arti } \\ \text { bacukui } & \text { bacukua } & \text { bercukur } \\ \text { batalui } & \text { batalua } & \text { bertelur } \\ \text { bapaluis } & \text { bapaluah } & \text { berkeringat }\end{array}$

Berdasarkan data di atas, dapat disimpulkan bahwa vokal rangkap akhir tiap-tiap bahasa berbeda. Vokal rangkap akhir [ui] merupakan pengucapan bahasa Jamee, sedangkan vokal rangkap akhir $[u a]$ merupakan pengucapan bahasa Minangkabau Bukittinggi.

Konsonan $[R]$ dan $[r]$

$\begin{array}{lll}{[\mathbf{R}](\mathbf{B J})} & {[\mathbf{r}](\mathbf{B M B})} & \text { Arti } \\ \text { bsRa } & \text { bara } & \text { berapa } \\ \text { saRewa } & \text { sarawa } & \text { celana } \\ \text { bacaRito } & \text { bacarito } & \text { bercerita } \\ \text { kaRajo } & \text { karajo } & \text { kerja } \\ \text { kaRih } & \text { karih } & \text { keris } \\ \text { Roten } & \text { roten } & \text { rotan }\end{array}$

Konsonan /r/ dilambangkan dengan $[\mathrm{R}]$ pada bahasa Jamee, sedangkan konsonan /r/ dilambangkan dengan [r] bahasa Minangkabau Bukittinggi. Konsonan $<\mathrm{r}>$ pada bahasa Jamee 
vibrasinya tidak terlalu jelas, tetapi masih terasa getaran di bawah dagu, sedangkan $<\mathrm{r}>$ pada bahasa Minangkabau Bukittinggi vibrasinya sangat jelas.

\section{Perbedaan Leksikal Bentuk Kata untuk Makna yang Sama antara Bahasa Jamee dan Bahasa Minangkabau Bukittinggi}

Perbedaan leksikal dari kedua bahasa yang dikaji di sini adalah pada bentuk kata untuk makna yang sama. Bentuk leksikal dari kedua bahasa dapat dilihat pada beberapa contoh /labang/, /paku/ dan /kepiang/, /pitih/. Kata labang bahasa Jamee memiliki makna yang sama dengan kata paku dalam bahasa Minangkabau Bukittinggi, dan kata /kepiang/ dalam bahasa Jamee memiliki makna yang sama dengan /pitih/ dalam bahasa Minangkabau Bukittinggi. Perbedaan leksikal tersebut dipengaruhi oleh adanya asimilasi bahasa Jamee dengan bahasa setempat, yaitu bahasa Aceh, sehingga bentuk leksikal dari kedua bahasa menjadi berbeda walaupun asal bahasa Jamee dari bahasa serumpun, yaitu bahasa Minangkabau. Beberapa contoh dapat dilihat pada tabel berikut ini.

Tabel 7. Bentuk Kata Berbeda untuk Makna yang Sama

\begin{tabular}{|c|c|c|c|}
\hline No. & BJ & BMB & Makna \\
\hline 1 & [labang] & [paku] & paku \\
\hline 2 & [kepia ] & [pitih] & uang \\
\hline 3 & [sakin] & [pisau] & pisau \\
\hline 4 & [aip] & [cacek/calo] & aib \\
\hline 5 & [makci'] & {$\left[\varepsilon t \varepsilon^{?}\right]$} & bibi \\
\hline 6 & [ambue] & [palantian] & pental \\
\hline 7 & [k\&na] & [embe] & ember \\
\hline 8 & [baba?] & [runtuah] & roboh \\
\hline 9 & [abo] & [pukua] & pukul \\
\hline 10 & [ambo] & [denai] & saya \\
\hline
\end{tabular}

\section{Perbedaan Morfologi Bahasa Jamee dan Bahasa Minangkabau Bukittinggi}

\subsection{Afiksasi}

Afiksasi adalah proses pembubuhan afiks (prefiks, infiks, sufiks, konfiks, dan simulfiks) pada kata dasar. Afiks yang terdapat pada bahasa Jamee sama dengan bahasa Minangkabau Bukittinggi, yaitu prefiks, infiks, sufiks, dan konfiks. Sebagaimana biasanya dalam bahasabahasa yang terdapat di Indonesia, dalam bahasa Jamee prefiks dihubungkan di awal kata, infiks dihubungkan di tengah-tengah kata atau antara konsonan dan vokal suku pertama kata dasar, dan sufiks dihubungkan di akhir kata dasar, sedangkan afiks pada akhir atau konfiks merupakan gabungan antara awalan dan akhiran yang memiliki satu kesatuan utuh.

\section{Awalan (prefiks)}

Pada umumnya prefiks yang digunakan dalam bahasa Jamee dan bahasa Minangkabau Bukittinggi memiliki kesamaan.

Sisipan (infiks)

Infiks bahasa Jamee adalah $\{-$ al- $\}$ dan $\{-$ ar- $\}$. Infiks ini tidak terdapat pada bahasa Minangkabau. Sebaliknya, infiks $\{-\mathrm{am}-\}$ dan $\{-\mathrm{um}-\}$ terdapat dalam bahasa Minangkabau Bukittinggi, tetapi tidak ditemukan dalam bahasa Jamee. Perhatikan contoh-contoh di bawah ini. 
BJ

Infiks $\{-a l-\}$

Igalatal

Igalawal

Infiks $\{-a r-\}$

/garudail

\section{BMB}

Infiks $\{-a m-\}$

/pamuncak/

/tirai-tamirail

Infiks $\{$-um- $\}$

/tumangguang/

/turun-tumurun/ 'geletar'

'kayu melempar '

'parutan'

'puncak'

'kain pintu'

'berwenang '

'turun- temurun'

\section{Akhiran (sufiks)}

Dalam bahasa Jamee terdapat sufiks $\{-\mathrm{en}\}$ dan $\{-\mathrm{ken}\}$, sedangkan bahasa Minangkabau Bukittinggi terdapat infiks $\{-a n\}$ dan $\{-$ kan $\}$. Perhatikan contoh-contoh di bawah ini.

\section{BJ}

$\{-\mathrm{en}\}$,

/kurunen/

/kampungen/

$\{-\mathrm{ken}\}$

/rumpuitken/

/kapurken/

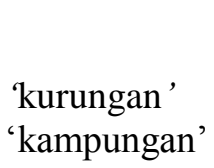

'rumputkan'

'kapurkan'

\section{BMB}

$\{-\mathrm{an}\}$

/kurungan/

/kampungan/

\{-kan\}

/rumpuikan/

/kapuakan/

\section{'kurungan' \\ 'kampungan' \\ 'rumputkan' \\ 'kapurkan'}

Gabungan imbuhan (konfiks)

Bahasa Jamee memiliki konfiks $\{$ ma-/-ken $\}$ dan $\{$ me-/-en\}, sedangkan bahasa Minangkabau Bukittinggi memiliki konfiks $\{$ ma-/-kan\}dan $\{$ ma- $/$-an $\}$, seperti dapat dilihat pada contohcontoh berikut.

\section{BJ}

\{me-/-ken $\}$

Imangaluaken/ 'mengeluarkan'

/mambunuahken/ 'membunuhkan'

$\{$ me-/-en $\}$

Imalaloken/ 'menidurkan'

/malempaen/ 'melemparkan'

\section{BMB}

$\{$ ma-/-kan $\}$
/mangaluakan/ 'mengeluarkan'
/mambunuahkan/'membunuhkan'
$\{$ ma-/-an $\}$
/malalokan/ 'menidurkan'
/maampoan/ 'melemparkan'

\subsection{Klasifikasi Kata}

Klasifikasi kata dibagi menjadi lima, yaitu verba, nomina, adjektiva, numerelia, dan adverbia.

Verba. Perbedaan verba atau kata kerja antara bahasa Jamee dan bahasa Minangkabau Bukittinggi dapat dilihat di bawah ini.

\section{BJ}

ImanaRe?

/banom/
BMB

/manguduaๆ/

/banam/

\section{Bahasa Indonesia}

'memotong'

'terbenam' 


\section{Nomina}

Perbedaan nomina atau kata benda antara bahasa Jamee dan bahasa Minangkabau Bukittinggi dapat dilihat di bawah ini.

$\begin{array}{lll}\text { BJ } & \text { BMB } & \text { Bahasa Indonesia } \\ \text { /kspian/ } & \text { /pitih/ } & \text { 'uang' } \\ \text { /sakin/ } & \text { /pisau/ } & \text { 'pisau' }\end{array}$

\section{Adjektiva}

Perbedaan adjektiva atau kata sifat antara bahasa Jamee dan bahasa Minangkabau Bukittinggi dapat dilihat di bawah ini.

$\begin{array}{lll}\text { BJ } & \text { BMB } & \text { Bahasa Indonesia } \\ \text { /cape'/ } & \text { /latiah/ } & \text { 'lelah' } \\ \text { /takwo/ } & \text { /sia'/ } & \text { 'takwa' }\end{array}$

\section{Numeralia}

Perbedaan numeralia atau kata bilangan antara bahasa Jamee dan bahasa Minangkabau Bukittinggi dapat dilihat di bawah ini.

$\begin{array}{lll}\text { BJ } & \text { BMB } & \text { Bahasa Indonesia } \\ \text { /tiop/ } & \text { /tio'/ } & \text { 'setiap' } \\ \text { /Samo } / & \text { /satandan/ } & \text { 'setandan' }\end{array}$

Adverbia

Perbedaan adverbia atau kata keterangan antara bahasa Jamee dan bahasa Minangkabau Bukittinggi dapat dilihat di bawah ini.

$\begin{array}{lll}\text { BJ } & \text { BMB } & \text { Bahasa Indonesia } \\ \text { lmantang/ } & \text { /lai/ } & \text { 'masih' } \\ \text { /isuak/ } & \text { /barisuak/ } & \text { 'besok' }\end{array}$

\subsection{Reduplikasi}

Reduplikasi atau pengulangan kata yang menunjukkan adanya perbedaan antara kedua bahasa dapat dilihat pada contoh-contoh berikut ini.

Kata Ulang Murni/Dwilingga

Kata ulang murni adalah kata ulang yang mengulang kata dasar tanpa ada perubahan satu pun. Kata ulang tersebut dapat dilihat pada contoh sebagai berikut.

$\begin{array}{lll}\text { BJ } & \text { BMB } & \text { Arti kata } \\ \text { sama-sama } & \text { samo-samo } & \text { sama-sama } \\ \text { malom-malom } & \text { malam-malam } & \text { malam-malam } \\ \text { koto-koto } & \text { lato-lato } & \text { kotor-kotor }\end{array}$

Kata Ulang Imbuhan

Kata ulang imbuhan adalah kata ulang yang perulangannya disisipi imbuhan. Jenis kata ulang dapat dilihat pada contoh sebagai berikut.

\section{BJ} manukik-nukik

\section{BMB}

mamakiak-makiak arti kata

memekik-mekik 


$\begin{array}{lll}\text { mamakn-maken } & \text { mamakan-makan } & \text { memakan-makan } \\ \text { manaRe-naRe } & \text { mangaduang-nguduang } & \text { memotong-motong }\end{array}$

Kata Ulang Perubahan Bunyi

Kata ulang perubahan bunyi adalah kata ulang yang mengalami perubahan bunyi pada perulangan kata. Jenis kata ulang ini dapat dilihat pada contoh sebagai berikut.

$\begin{array}{lll}\text { BJ } & \text { BMB } & \text { arti kata } \\ \text { ceRe-beRei } & \text { carai-barai } & \text { cerai-berai } \\ \text { kedap-kedip } & \text { kijok-kijok } & \text { kedap-kedip }\end{array}$

Kata Ulang Semu

Kata ulang semu adalah kata ulang yang jika tidak diulang tidak memiliki arti yang sama pada saat diulang atau mempunyai makna beda pada saat diulang. Contohnya dapat dilihat sebagai berikut.

$\begin{array}{lll}\text { BJ } & \text { BMB } & \text { arti kata } \\ \text { aRi-aRi } & \text { ari-ari } & \text { 'ari-ari' } \\ \text { kuRo-kuRo } & \text { labi-labi } & \text { 'kura-kura' }\end{array}$

\section{Perbedaan Struktur Sintaksis Bahasa Jamee dan Bahasa Minangkabau Bukittinggi}

Dalam bahasa Jamee dan bahasa Minangkabau Bukittinggi, suatu ujaran bebas yang memberikan informasi lengkap memerlukan dua kata dasar. Satu kata dasar berfungsi sebagai subjek dan satu lagi sebagai predikat. Predikat mengungkapkan suatu tindakan yang dilakukan atau diderita. Predikat merupakan salah satu unsur yang sangat penting jika dibandingkan dengan unsur-unsur lain. Struktur pola kalimat bahasa Jamee dan bahasa Minangkabau Bukittinggi memiliki kesamaan, yaitu dimulai dari unsur subjek, predikat, dan diikuti unsurunsur lain. Pola kalimat itu terdiri atas S-P, S-P-O, S-P-Pel, S-P-K, S-P-O-Pel, S-P-Pel-K, S-PO-K, S-P-O-Pel-K. Contoh pola kalimat kedua bahasa dapat dilihat sebagai berikut.

(1) a. Umah ambo tapanggang. (BJ)

'Rumah saya terbakar.'

$\mathrm{S}$

$$
\mathrm{P}
$$

b. Rumah den tabaka. (BMB)

'Rumah saya terbakar.'

$$
\mathrm{S} \quad \mathrm{P}
$$

(2) a. Uniang tangah makcn mampolam. (BJ)

'Kakak sedang makan mangga.'

$\begin{array}{lll}\mathrm{S} & \mathrm{P} & \mathrm{O}\end{array}$

b. Uni sadang makan mangga. (BMB)

'Kakak sedang makan mangga.'
S
$\mathrm{P}$
$\mathrm{O}$

(3) a. Putri bamain karet. (BJ)

'Putri bermain karet.'

S P Pel

b. Putri bamain kajai. (BMB)

'Putri bermain karet.'

S P Pel 
(4) a. Tantuwen pai ka Jakarta. (BJ)

'Paman pergi ke Jakarta.'

$$
\mathrm{S} \quad \mathrm{P} \quad \mathrm{K}
$$

b. Aciak pai ka Jakarta. (BMB)

'Paman pergi ke Jakarta.'

$$
\text { S P K }
$$

Proses pembentukan kalimat dalam bahasa Jamee dan bahasa Minangkabau Bukittinggi terjadi melalui proses (1) perluasan kalimat dan (2) penggabungan kalimat.

\subsection{Perluasan Kalimat}

Dalam bahasa Jamee dan bahasa Minangkabau Bukittinggi setiap unsur kalimat dapat diperluas. Unsur-unsur yang diperluas adalah subjek, predikat, objek, atau keterangan. Tidak ada perbedaan yang mendasar di dalam perluasan kalimat dari kedua bahasa. Perhatikan beberapa contoh di bawah ini.

(5) a. Unyang yang tangah mancuci tu Unyang ayah. (BJ)

'Nenek yang sedang mencuci itu adalah nenek ayah.'

$$
\text { S P Pel }
$$

b. Inyiak nan tangah manyasah tu Inyiak apak. (BMB)

'Nenek yang sedang mencuci itu adalah nenek ayah.'

$$
\text { S P Pel }
$$

(6) a. Alot tangah manjua apom. (BJ)

'Bibi sedang menjual serabi.'

$\mathrm{S} \quad \mathrm{P} \quad \mathrm{O}$

b. Etek sadang manjua sarabi. (BMB)

'Bibi sedang menjual serabi.'

$$
\begin{array}{lll}
\mathrm{S} & \mathrm{P} & \mathrm{O}
\end{array}
$$

(7) a. Hasni mambali kue yang bersalai naneh di kadai. (BJ)

'Hasni membeli kue yang berselai nanas di kios.'
$\mathrm{P}$
$\mathrm{O}$
$\mathrm{K}$

b. Hasni mambali kue yang basalai naneh di lapau. (BMB)

'Hasni membeli kue yang berselai nanas di kios.'
$\mathrm{S}$
$\mathrm{P}$
$\mathrm{O}$
$\mathrm{K}$

(8) a. Rika pai ka Bandung jok moto. (BJ)

'Rika pergi ke Bandung dengan motor.'

$\mathrm{S} \mathrm{P} \quad \mathrm{K}$

b. Rika pai ka Bandung jo oto. (BMB)

'Rika pergi ke Bandung dengan motor.'

$\mathrm{S} \quad \mathrm{P}$

\subsection{Penggabungan Kalimat}

Kalimat tunggal yang digabungkan dapat menjadi kalimat majemuk setara atau kalimat majemuk bertingkat. Kedua jenis kalimat ini terdapat dalam bahasa Jamee dan bahasa Minangkabau Bukittinggi. Penggabungan kalimat tersebut memiliki kesamaan di antara kedua bahasa tersebut. Perhatikan contoh-contoh berikut. 
(9) a. Marshal mambaco buku caRito, Tia manulih PR. (BJ)

'Marshal membaca buku cerita, Tia menulis PR.'

$\begin{array}{llllll}\mathrm{S} & \mathrm{P} & \mathrm{O} & \mathrm{S} & \mathrm{P} & \mathrm{O}\end{array}$

b. Marshal mambaco buku carito, Tia manulih PR. (BMB)

'Marshal membaca buku cerita, Tia menulis PR.'
$\mathrm{S}$
$\mathrm{P}$
$\begin{array}{llll}\mathrm{O} & \mathrm{S} & \mathrm{P} & \mathrm{O}\end{array}$

(10) a. Kalao ayom bakokok, kami bangun pagi. (BJ)

'Kalau ayam berkicau, kami bangun pagi.'

$\begin{array}{llll}\mathrm{K} & \mathrm{S} & \mathrm{P} & \mathrm{K}\end{array}$

b. Kalau ayam bakokok, kami jago pagi (BMB)

'Kalau ayam berkicau, kami bangun pagi.'

$\begin{array}{llll}\mathrm{K} & \mathrm{S} & \mathrm{P} & \mathrm{K}\end{array}$

\section{SIMPULAN}

Berdasarkan hasil penelitian di atas, dapat digambarkan bahwa bahasa Jamee dan bahasa Minangkabau Bukittinggi memiliki banyak persamaan dan sedikit perbedaan. Banyaknya persamaan ini karena bahasa Jamee masih serumpun dengan bahasa Minangkabau Bukittinggi. Perbedaannya hanya terletak pada sebagian ruang lingkup fonologi dan sebagian morfologi. Dalam hal struktur kalimat, kedua bahasa tidak memiliki perbedaan.

Dalam hal fonologi, perbedaannya terletak pada sistem vokal dan sistem konsonan. Vokal $/ \varepsilon /$ dan $/ \supset /$ merupakan vokal yang terdapat dalam bahasa Jamee, sedangkan dalam bahasa Minangkabau Bukittinggi vokal tersebut tidak ditemukan. Selain itu, terdapat juga perbedaan pada vokal rangkap, yaitu vokal rangkap /ue/, /ie/, dan /ui/. Vokal rangkap /ue/, /ie/, dan /ui/ merupakan vokal rangkap bahasa Jamee dan vokal rangkap /ua/, /ie/, dan /ia/ merupakan vokal rangkap bahasa Minangkabau Bukittinggi. Pada sistem konsonan, konsonan $/ y /$ ada dalam bahasa Jamee, sedangkan konsonan / $r$ / ada dalam bahasa Minangkabau Bukittinggi.

Dalam hal morfologi, perbedaan yang dominan ada pada kelas atau klasifikasi kata dan sebagian afiksasi, sedangkan reduplikasi memiliki kesamaan. Perbedaan pada kelas kata banyak ditemukan pada nomina, verba, adjektiva, sedangkan pada numeralia dan adverbia hanya sedikit ditemukan perbedaannya. Pada afiksasi, perbedaan kedua bahasa terletak pada infiks, sufiks, dan konfiks, sedangkan kesamaan ada pada prefiks.

\section{CATATAN}

*Penulis berterimakasih kepada mitra bestari yang telah memberikan saran-saran dan masukan yang sangat berarti untuk perbaikan tulisan ini.

\section{DAFTAR PUSTAKA}

Abdullah, W., Marlian, R., \& Gade. (1990). Struktur Bahasa Jamee. Jakarta: Proyek Penelitian Bahasa dan Sastra Indonesia dan Sastra.

Ayub, A. (2008). Tata Bahasa Minangkabau. Jakarta: Pusat Pembinaan dan Pengembangan Bahasa, Departemen Pendidikan dan Kebudayaan.

Burhanuddin, E. (2009). Kamus Bahasa Minangkabau-Indonesia. Padang: Balai Bahasa Padang, Departemen Pendidikan dan Kebudayaan. 
Hasanah, E. (2015). Analisis Komparatif Antara Bahasa Jawa Dialek Jember dan Bahasa Jawa Standar. Jurnal Republika Budaya, 1, 2--11.

Mahsun. (2005). Metode Penelitian Bahasa: Tahapan Strategi, Metode, dan Tekniknya. Jakarta: Raja Grafindo Persada.

Moussay, G. (1998). Tata Bahasa Minangkabau. Jakarta: Kepustakaan Populer Gramedia.

Samarin, W.J. (1988). Ilmu Bahasa Lapangan. Yogyakarta: Kanisius.

Sufi, R. (1998). Keanekaragaman Suku dan Budaya Aceh. Banda Aceh: Departemen Pendidikan dan Kebudayaan, Balai Kajian Sejarah dan Nilai Tradisional.

Sugiyono. (2008). Metode Penelitian Kuantitatif, Kualitatif, dan R\&D. Bandung: Alfabeta. 